\title{
Occurrence of Malabar Snakehead, Channa diplogramma (Perciformes: Channidae) from River Valapattanam, Western Ghats of Kerala, India
}

\author{
Sajan Sajeevan, ${ }^{1}$ Anna Mercy T. Varkey, ${ }^{1}$ and Mithun Sukumaran ${ }^{2}$ \\ ${ }^{1}$ Faculty of Fisheries, College of Fisheries, Kerala University of Fisheries and Ocean Studies, Ernakulum, Kerala 682 506, India \\ ${ }^{2}$ School of Applied Science, Temasek Polytechnic, 21 Tampines Avenue 1, Singapore 529757 \\ Correspondence should be addressed to Sajan Sajeevan; sajanpolayil@gmail.com
}

Received 25 April 2014; Revised 28 May 2014; Accepted 24 June 2014; Published 8 July 2014

Academic Editor: Calum MacNeil

Copyright (c) 2014 Sajan Sajeevan et al. This is an open access article distributed under the Creative Commons Attribution License, which permits unrestricted use, distribution, and reproduction in any medium, provided the original work is properly cited.

We report the occurrence of Channa diplogramma in the Valapattanam River in March 2013 and this study adds to the species record of C. diplogramma in terms of diversity and range distribution in the River Valapattanam and South India.

\section{Introduction}

Freshwater snakehead fishes of the family Channidae have widespread distribution in the tropics [1], represented by 38 species, of which 35 are of the Asian genus Channa [2] and three of the African genus Parachanna [1, 3, 4]. The Western Ghats biodiversity of India extends along the west coast and is crisscrossed with many streams, which form the major rivers draining water to the plains of Peninsular India [5]. The freshwater fish diversity in the Western Ghats hotspots is very high [6], with 320 species belonging to 212 endemic species $47 \%$ being under Threatened or Near Threatened categories and 23\% being under Data Deficient or Not Evaluated categories [7]. The Valapattanam River is one of the west-flowing Rivers in the Western Ghats region of India and the main tributaries are Srikandapurampuzha, Bavalipuzha, Venipuzha, and Aralampuzha. In this paper, we report the occurrence and biometric characteristics of $C$. diplogramma (Day 1865) [8] from the river Valapattanam, Western Ghats of Kerala, India.

\section{Materials and Methods}

A specimen of C. diplogramma (Figure 1) was caught with an encircling net (length 50 meter; height 1.5 meter; mesh size $0.8 \mathrm{~mm}$ ) from the River Valapattanam, northern Kerala $\left(11.93^{\circ} \mathrm{N}, 75.30^{\circ} \mathrm{E}\right)$ on 15 March 2013. The morphometric measurements of the formalin-preserved specimen were measured with a Vernier calliper to the nearest 0.1 millimetres and weighed to the nearest 0.01 gram using an electric balance (Sartorius-GD-603). The morphometric measurements and meristic counts were made by following $\mathrm{Ng}$ et al. [9]. Measurements of body parts are reported as percentage of standard length (\%SL) and measurements of subunits of head are reported as percentage of head length (\%HL). The specimen was preserved in $4 \%$ formaldehyde solution and deposited in the Museum of the Faculty of Fisheries, College of Fisheries, Kerala University of Fisheries and Ocean Studies, Panangad, Kerala, India (FRM-CH-DIP/2013-1).

\section{Results and Discussion}

Channa diplogramma was first described as Ophiocephalus diplogramma (Day 1865) based on one juvenile specimen (42 mm in length) collected near the mouth of the Cochin estuary in the port city of Cochin (Kerala, India). The close similarity of this juvenile specimen with C. micropeltes, originally described by Cuvier and Valenciennes [10] from Indonesia, may have misled author to synonymise $C$. diplogramma with C. micropeltes [11]. Recently researchers suggested that $C$. diplogramma is distinct from C. micropeltes and should be considered as a valid species [12,13]. After 134 


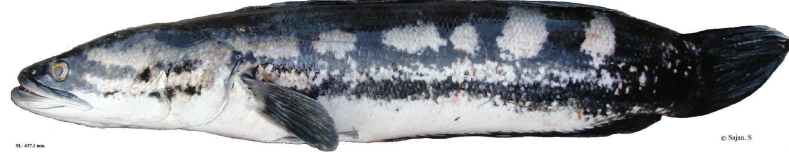

FIGURE 1: Channa diplogramma caught from the River Valapattanam (lateral view).

years of it being synonymised, C. diplogramma is known to be a valid endemic species of Peninsular India [11]. Channa diplogramma is endemic to southern Western Ghats region of India, where it has been reported from the River Meenachil, Manimala, Pampa, Achankovil, and Kallada in Kerala state, as well as the River Chittar and Tambraparni in Tamil Nadu state $[11,14,15]$. Benziger et al. [11] reported that they used comparative specimens of $C$. diplogramma from Canara and Mangalore region of south India, but there is no specific record from River Valapattanam [11]. This species has not been reported from the Valapattanam River in earlier works $[16,17]$. Hence, this current record adds to the recorded ichthyodiversity of River Valapattanam in Kerala (Figure 2).

The morphometric and meristic characters of the collected C. diplogramma are presented in Tables 1 and 2. All the morphometric measurements and meristic counts of the current specimen were in the prescribed range for C. diplogramma as described by Benziger et al. [11]. Some researchers have used molecular analysis methods for the taxonomic identification of a species $[2,12,18,19]$; however, we could not follow the molecular analysis in the current study. Benziger et al. [11] reported that C. diplogramma, collected from the riverine system of Kerala, had 103-105 lateral line scales, which was more than all other species in this genus. Similarly, the current specimen also had 104 lateral line scales and has a relatively long broad body with a laterally compressed head.

Snakeheads are very hardy animals due to the presence of several biological features that they share among their family [18]. In the present study C. diplogramma was collected from middle stream part of the river, pool type of habitat with riparian shade and bottom with rock, gravel, and sand. Banks of the site was supported with shrubs and trees giving strong shade into the water. In nature, snakeheads are carnivorous which feed only on live animals including small fishes, insects, crustaceans, frogs, and even baby turtles [20]. Mohsin and Ambak [21] and Roberts [22] noted that C. micropeltes kills more individual fish than it actually eats (i.e., not all prey is consumed); likewise, $C$. diplogramma may possibly be a biological threat to the small indigenous freshwater fishes in these rivers [18]. To understand its effects over indigenous freshwater fish diversity, more studies are to be conducted.

Due to the attractive colour pattern of juveniles of $C$. diplogramma, they have been overexploited from the wild for the international aquarium pet trade [23]. However, this profitable business sometimes poses a threat to the environment especially in places where snakehead is not a native fish since some of the fish find their way into dams, rivers, and other water bodies, either by accident or otherwise by being released by traders or by hobbyists
TABLE 1: Morphometric measurements of the Channa diplogramma.

\begin{tabular}{|c|c|c|}
\hline Character & $\begin{array}{l}\text { Measurement } \\
(\mathrm{mm})\end{array}$ & $\%$ of Standard Length \\
\hline Total length & 534.1 & \\
\hline Standard length & 437.1 & \\
\hline Head length & 145.2 & 33.2 \\
\hline Head width & 85.1 & 19.5 \\
\hline Head depth & 73.6 & 16.8 \\
\hline Body depth & 92.0 & 21.1 \\
\hline Body width & 91.3 & 20.9 \\
\hline Predorsal length & 154.2 & 35.3 \\
\hline Preanal length & 221.1 & 50.6 \\
\hline Prepectoral length & 149.1 & 34.1 \\
\hline Prepelvic length & 155.3 & 35.5 \\
\hline Dorsal fin base length & 282.1 & 64.5 \\
\hline Anal fin base length & 169.1 & 38.7 \\
\hline Caudal peduncle length & 61.1 & 14.0 \\
\hline Caudal peduncle depth & 58.5 & 13.4 \\
\hline Caudal fin length & 97.1 & 22.2 \\
\hline Orbital diameter & 16.1 & 3.6 \\
\hline Preorbital length & 33.2 & 7.6 \\
\hline Postorbital length & 108.9 & 24.9 \\
\hline Inter orbital width & 48.9 & 11.2 \\
\hline Jaw length & 61.2 & 14.0 \\
\hline Jaw width & 54.1 & 12.4 \\
\hline Gape width & 21.1 & 4.8 \\
\hline Dorsal fin length & 36.1 & 8.2 \\
\hline Pectoral fin length & 65.6 & 15.0 \\
\hline Pectoral fin base length & 24.1 & 5.5 \\
\hline Pelvic fin length & 55.1 & 12.6 \\
\hline Anal fin length & 32.1 & 7.3 \\
\hline Character & Measurement & $\%$ of Head length \\
\hline Head width & 85.1 & 58.6 \\
\hline Head depth & 73.6 & 50.7 \\
\hline Orbital diameter & 16.1 & 11.1 \\
\hline Preorbital length & 33.2 & 22.9 \\
\hline Postorbital length & 108.9 & 75.0 \\
\hline Inter orbital width & 48.9 & 33.7 \\
\hline Jaw length & 61.2 & 42.1 \\
\hline Jaw width & 54.1 & 37.3 \\
\hline Gape width & 21.1 & 14.5 \\
\hline
\end{tabular}

when they mature into less attractive colours [18]. Channa diplogramma shows a similar pattern of body colouration as in C. micropeltes [11]; the current specimen showed to be dark blue with white spots along the whole of its profile down to its white underside. According to Benziger et al. [11], C. diplogramma shows multiple colour stages during its life history, which makes local fishermen believe that they are different species. Because of this colour differentiation, $C$. diplogramma is locally known by different vernacular names 
TABLE 2: Meristic data of the Channa diplogramma.

\begin{tabular}{lc}
\hline Character & Number \\
\hline Dorsal fin rays & 42 \\
Anal fin rays & 27 \\
Pectoral fin rays & 15 \\
Pelvic fin rays & 6 \\
Lateral line scales & 104 \\
Scales above Lateral line & 7 \\
Scales below Lateral Line & 16 \\
\hline
\end{tabular}

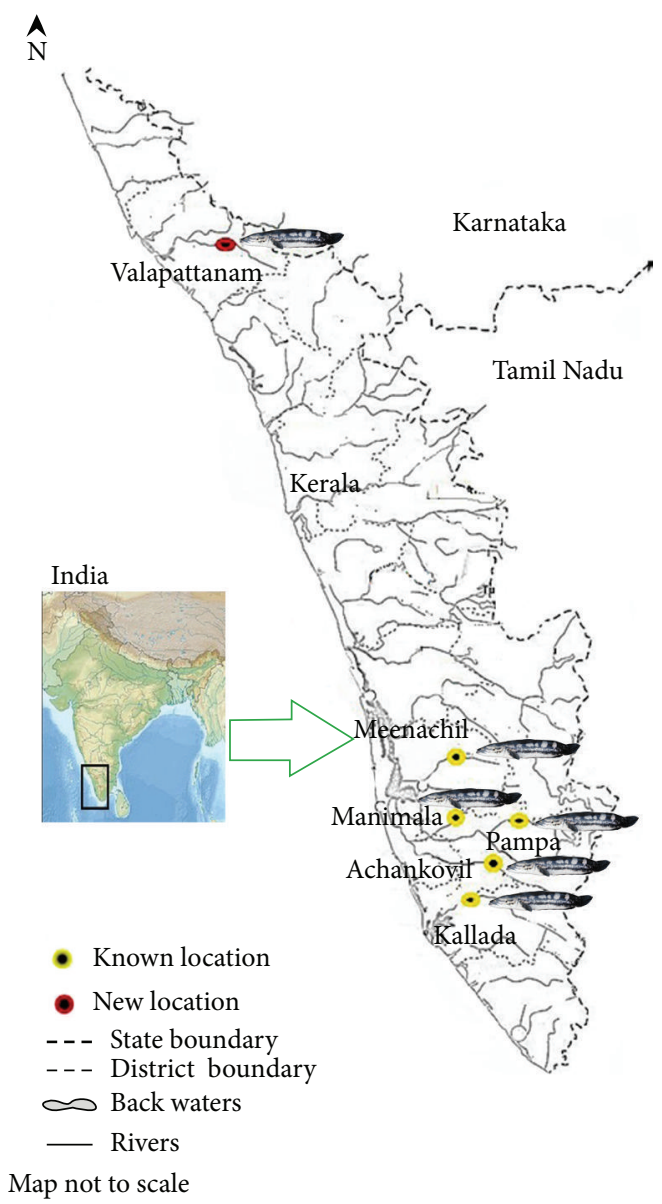

FIGURE 2: Distribution of Channa diplogramma in the rivers of Kerala.

such as Puli vaka, Kari vaka, Manal vaka, Charal vaka, and Vaka varal. The current female specimen measured $534.1 \mathrm{~mm}$ in total length and $1720 \mathrm{~g}$ in body weight. The spent stage of ovarian maturity was observed in the current specimen of C. diplogramma caught in March, which may be helpful for future biological and conservation studies in C. diplogramma

The population of $C$. diplogramma is declining due to the overexploitation for consumption and aquarium trading [1, 11]. A recent study revealed that $C$. diplogramma contributed 0.79 tonnes in the exploited fishery from River Pampa [24]. Kurup and Ranjeeth [25] reported that the population of C. diplogramma has declined significantly over the last two decades in the rivers of Kerala (>90\%). Kurup [26] noticed that this species was subjected to alarming decline in its population due to destructive type of fishing activities including dynamiting and poisoning, EUS, habitat alteration, and pollution. Consulting the local fishermen and fish collectors in the River Valapattanam, it is known that C. diplogramma is caught occasionally by artisanal fishing, namely, seine netting, gill netting, or long lining. Our personal observations and discussions with local fishermen reveal that most of the extensive fishing of $C$. diplogramma was carried out during the monsoon season. Habitat destruction and sand mining in the river basin of Valapattanam have posed serious problems to the freshwater fish population by affecting their breeding and spawning grounds. Due to its restricted distribution, small population size, illegal fishing, and anthropogenic pressure to its natural habitats, the species is classified under Vulnerable by the IUCN [27]. However, the present record is nevertheless significant in extending recorded distribution of C. diplogramma in the Western Ghats of India.

\section{Conflict of Interests}

The authors declare that there is no conflict of interests regarding the publication of this paper.

\section{References}

[1] X. Li, P. Musikasinthorn, and Y. Kumazawa, "Molecular phylogenetic analysis of snakeheads (Perciformes: Channidae) using mitochondrial DNA sequences," Ichthyological Research, vol. 53, pp. 148-159, 2005.

[2] Fish Base, http://www.fishbase.org/identification/SpeciesList. php?genus=Channa\# result.

[3] W. R. Courtenay Jr. and J. D. Williams, "Snakeheads (PiscesChannidae)_A biological synopsis and risk assessment," U.S. Geological Survey Circular, vol. 1251, p. 151, 2004.

[4] M. Kottelat, S. R. Kartikasari, A. J. Whitten, S. N. Kartikasari, and S. Wirjoatmodjo, Freshwater Fishes of Western Indonesia and Sulawesi: Indonesia, Periplus Editions (HK), 1993.

[5] G. Prasad, K. Sabu, and P. V. Prathibhakumari, "The first report of the Malabar puffer, Carinotetraodon travancoricus (Hora \& Nair, 1941) from the Neyyar wildlife sanctuary with a note on its feeding habit and length-weight relationship," Journal on New Biological Reports, vol. 1, no. 2, pp. 42-46, 2012.

[6] N. Myers, R. A. Mittermeler, C. G. Mittermeler, G. A. B. da Fonseca, and J. Kent, "Biodiversity hotspots for conservation priorities," Nature, vol. 403, no. 6772, pp. 853-858, 2000.

[7] N. Dahanukar and R. Raghavan, "Freshwater fishes of the Western Ghats: Checklist," Min, vol. 1, pp. 6-16, 2013.

[8] F. Day, "Fishes of Cochin, on the Malabar coast of India-part I: Acanthopterygii," in Proceedings of the General Meetings for Scientific Business of the Zoological Society of London, pp. 2-40, 1865.

[9] H. H. Ng, S. H. Tan, and P. K. L. Ng, A Guide to the Freshwater Fishes of Singapore, Singapore Science Centre, Singapore, 1991.

[10] G. Cuvier and A. Valenciennes, Histoire Naturelle des Poisons, vol. 7, Levrault, Paris, France.

[11] A. Benziger, S. Philip, R. Raghavan et al., "Unraveling a 146 years old taxonomic puzzle: validation of Malabar snakehead, 
species-status and its relevance for Channid systematics and evolution," PLoS ONE, vol. 6, no. 6, Article ID e21272, 2011.

[12] E. A. S. Adamson, D. A. Hurwood, and P. B. Mather, "A reappraisal of the evolution of Asian snakehead fishes (Pisces, Channidae) using molecular data from multiple genes and fossil calibration," Molecular Phylogenetics and Evolution, vol. 56, no. 2, pp. 707-717, 2010.

[13] M. Kottelat, "Fish of the Nam Theun and Xe Bangfai Basins, Laos, with diagnoses of twenty-two new species (Teleostei: Cyprinidae, Balitoridae, Cobitidae, Coiidae and Odontobutidae)," Ichthyological Exploration of Freshwaters, vol. 9, no. 1, pp. 1-128, 1998.

[14] J. Ebanasar and V. Jayaprakas, "Length-weight relationship of the Malabar snakehehead Channa micropeltes from Pechipparai Reservoir, Kanyakumari District, Tamil Nadu," Journal of the Inland Fisheries Society, vol. 37, no. 1, pp. 60-63, 2003.

[15] K. C. Jayaram, The Freshwater Fishes of the Indian Region, Narendra Publication, New Delhi, India, 1999.

[16] P. S. Easa and C. P. Shaji, "Freshwater fish diversity in Kerala part of the Nilgiri Biosphere Reserve," Current Science, vol. 73, no. 2, pp. 180-182, 1997.

[17] C. R. Biju, Habitat and distribution of hill stream fishes of Northern Kerala [Ph.D. thesis], Mahatma Gandhi University, Kerala, India, 2003.

[18] B. M. H. Norainy, Morphological and genetic variability of Malaysian Channa spp based on morphometric and RAPD techniques, [Msc. thesis], University Sains Malaysia, Pulau Penang, Malaysia, 2007.

[19] D. Scot, J. W. Moore, L. Herborg, C. C. Murray, and N. R. Serrao, "A non-native snakehead fish in British Columbia, Canada: capture, genetics, isotopes, and policy consequences," Management of Biological Invasions, vol. 4, no. 4, pp. 265-271, 2013.

[20] P. G. Lee and P. K. L. Ng, "The systematics and ecology of snakeheads (Pisces: Channidae) in Peninsular Malaysia and Singapore," Hydrobiologia, vol. 285, no. 1-3, pp. 59-74, 1994.

[21] A. K. M. Mohsin and M. A. Ambak, Freshwater Fishes of Peninsular Malaysia, Universiti Pertanian Malaysia Press, Kuala Lumpur, Malaysia, 1983.

[22] T. R. Roberts, The Freshwater Fishes of Western Borneo (Kalimantan Barat, Indonesia), Memoirs of the California Academy of Science, San Francisco, Calif, USA, 1989.

[23] E. A. S. Adamson, Influence of historical landscapes, drainage evolution and ecological traits on patterns of genetic diversity in South East Asian freshwater snakehead fishes [Ph.D. thesis], Queensland University of Technology, Brisbane, Australia, 2010.

[24] C. R. Renjithkumar, M. Harikrishnan, and B. M. Kurup, "Exploited fisheries resources of the Pampa river, Kerala, India," Indian Journal of Fisheries, vol. 58, no. 3, pp. 13-22, 2011.

[25] B. M. Kurup and Ranjeeth, "Invasion of exotic fish population in Periyar Lake, Kerala: a hotspot of fish biodiversity," in Proceedings of the Life History Traits of Freshwater Fish Population for Its Utilization in Conservation, NBFGR-NATP, AC-15, pp. 1-4, Lucknow , India, 2002.

[26] B. M. Kurup, "Management plans to arrest the decline of freshwater fish diversity of Kerala," in Endemic Fish Diversity of Western Ghats, A. G. Ponniah and A. Gopalakrishnan, Eds., pp. 164-166, NBFGR-NATP National Bureau of Fish Genetic Resources, Lucknow, India, 2000.
[27] R. Abraham, "Channa diplogramma. In: IUCN 2013. IUCN red list of threatened species," Version 2013, http://www.iucnredlist.org/. 

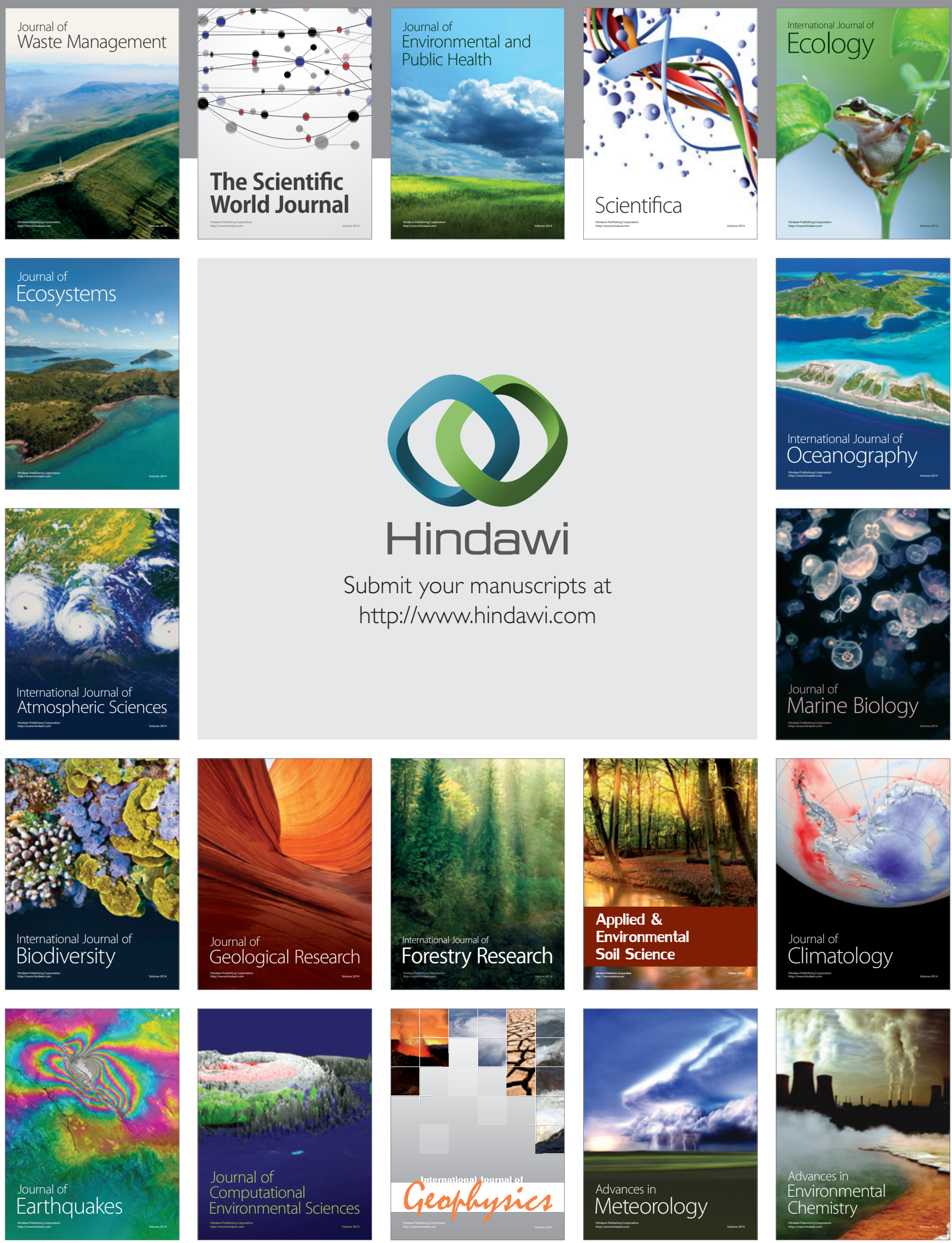